\title{
Developing Limited Proteolysis and Mass Spectrometry for the Characterization of Ribosome Topography
}

\author{
Moo-Jin Suh, , Soheil Pourshahian, and Patrick A. Limbach \\ Department of Chemistry, Rieveschl Laboratories for Mass Spectrometry, Cincinnati, Ohio, USA
}

\begin{abstract}
An approach that combines limited proteolysis and matrix-assisted laser desorption/ionization mass spectrometry (MALDI-MS) has been developed to probe protease-accessible sites of ribosomal proteins from intact ribosomes. Escherichia coli and Thermus thermophilus $70 \mathrm{~S}$ ribosomes were subjected to limited proteolysis using different proteases under strictly controlled conditions. Intact ribosomal proteins and large proteolytic peptides were recovered and directly analyzed by MALDI-MS, which allows for the determination of proteins that are resistant to proteolytic digestion by accurate measurement of molecular weights. Larger proteolytic peptides can be directly identified by the combination of measured mass, enzyme specificity, and protein database searching. Sucrose density gradient centrifugation revealed that the majority of the 70S ribosome dissociates into intact $30 \mathrm{~S}$ and $50 \mathrm{~S}$ subunits after $120 \mathrm{~min}$ of limited proteolysis. Thus, examination of ribosome populations within the first 30 to $60 \mathrm{~min}$ of incubation provides insight into $70 \mathrm{~S}$ structural features. Results from E. coli and T. thermophilus revealed that a significantly larger fraction of $50 \mathrm{~S}$ ribosomal proteins have similar limited proteolysis behavior than the $30 \mathrm{~S}$ ribosomal proteins of these two organisms. The data obtained by this approach correlate with information available from the high-resolution crystal structures of both organisms. This new approach will be applicable to investigations of other large ribonucleoprotein complexes, is readily extendable to ribosomes from other organisms, and can facilitate additional structural studies on ribosome assembly intermediates. (J Am Soc Mass Spectrom 2007, 18, 1304-1317) (c) 2007 American Society for Mass Spectrometry
\end{abstract}

$\mathrm{T}$ The ribosome, found in all organisms, is the subcellular organelle that performs the activity of protein synthesis. Prokaryotic ribosomes, which sediment at 70S, have a molecular mass of $\sim 2.5 \times 10^{6}$ $\mathrm{Da}$ and consist of two subunits, the 50S and the 30S. Each subunit has a unique number of proteins and ribosomal RNAs (rRNAs). Eukaryotic ribosomes, which sediment at $80 \mathrm{~S}$, are substantially larger and more complex than their prokaryotic counterparts. Two subunits, the $60 \mathrm{~S}$ and $40 \mathrm{~S}$, together contain at least 78 unique proteins and 4 rRNAs. The small subunit binds messenger RNA (mRNA) and mediates the interactions between mRNA and transfer RNAs (tRNAs). The larger subunit catalyzes peptide-bond formation. During the initiation phase of protein synthesis, the two subunits behave independently, assembling into complete ribosomes only when elongation is about to begin.

A fundamental prerequisite for understanding the biochemical interactions occurring within the ribosome during protein synthesis is a detailed knowledge of the structure of this ribonucleoprotein (RNP) complex. Some of the more successful approaches for character-

Address reprint requests to Dr. P. A. Limbach, Department of Chemistry, Rieveschl Laboratories for Mass Spectrometry, P.O. Box 210172, University of Cincinnati, Cincinnati, OH 45221-0172, USA. E-mail: Pat.Limbach@uc.edu

* Current address: Department of Pharmacology, Weill Medical College, Cornell University, New York, NY 10021, USA. izing ribosomes include crosslinking [1-4], cryoelectron microscopy (cryo-EM) [5-7], tritium bombardment [8], nuclear magnetic resonance (NMR) [9] and electrospray mass spectrometry [10-13]. One of the most successful approaches has been the development of X-ray crystallography within the past several years, wherein high-resolution crystal structures of ribosomal subunits or intact ribosomes have been obtained that provide detailed structural information at the atomic level [14-18]. However, as noted recently by Selmer et al. [18], the presence of crystal structures alone does not translate into an accurate assignment of ribosomal proteins. Thus, analytical approaches that can provide information regarding ribosome components, organization and topology, and that are readily extendable to new organisms will assist in structural assignments as ribosomes from new organisms are crystallized and studied.

Limited proteolysis has been used to investigate structure-function relationships in proteins and the interacting sites in protein-nucleic acid complexes [1921]. Limited proteolysis can reveal details of the exposed sites of protein-nucleic acid complexes, which is useful for modeling three-dimensional structures. While limited proteolysis yields useful information regarding the topology of biomolecules, it has not been widely applied to studies of RNP complexes in general, 
or the ribosome in particular, due to the complexity of data interpretation as previous investigations of the ribosome by this approach relied upon 2-D gel electrophoresis as the separation/detection scheme [22, 23].

Mass spectrometry has been used as the readout step in a limited proteolysis approach for characterizing macromolecular structure [24-29]. In those previous reports, single proteins with nucleic acids or ligands $[24,26]$ or virus complexes [28] were investigated by limited proteolysis with mass spectrometry. Most limited proteolysis studies previously reported have been carried out for observing the conformational change of a protein with and without bound nucleic acid or ligands, and for probing the structural and dynamic differences between the holo and apo form of a protein [25]. Based on the interaction between a protein and a nucleic acid or ligand, the stable domain of a protein or the likely sites of binding within the protein could be directly determined by mass spectrometry without requiring sample isolation after limited proteolysis.

Here we expand the use of limited proteolysis with matrix-assisted laser desorption/ionization mass spectrometry (MALDI-MS) to a much larger and more complex macromolecular assembly containing multiple proteins and RNAs. In the present study, the proteaseaccessible sites of ribosomal proteins (r-proteins) within Escherichia coli and Thermus thermophilus intact 705 ribosomes have been identified by a combination of limited proteolysis and MALDI-MS. With this approach, undigested proteins can be unambiguously assigned based upon their accurately measured molecular weights. By comparative limited proteolysis using trypsin and Proteinase $\mathrm{K}$, the r-proteins whose surface exposed regions are resistant to trypsin but not general proteolysis were identified. We identified six small subunit r-proteins and 22 large subunit r-proteins that are resistant to limited proteolysis using trypsin in both E. coli and $T$. thermophilus. In addition, some proteins were determined to be stable in their truncated form and are retained within the ribosomal subunit structures. As existing E. coli and T. thermophilus crystal structures were used to confirm the results found in this study, this new approach should be applicable to examining ribosomes whose topology or crystal structures are not yet known and can help inform future structural characterizations of ribosomal subunits or intact ribosomes.

\section{Experimental}

\section{Materials}

Tryptone and yeast extract were obtained from Difco Labs (Detroit, MI). Buffer reagents, Proteinase K, and the MALDI peptide calibration kit were obtained from Sigma (St. Louis, MO). Sinapinic acid (SA) and $\alpha$-cyano4-hydroxycinnamic acid (CHCA) were obtained from Fluka (Milwaukee, WI). Acids and organic solvents were HPLC grade or better. Trypsin (sequencing grade) and DNase were purchased from Promega (Madison, MI).

\section{Preparation of 705 Ribosomes}

Thermus thermophilus HB8 (ATCC 27,642) was a gift from S. Gregory and A. Dahlberg (Brown University, Providence RI), and conditions for culturing $T$. thermophilus and isolating 705 ribosomes have been described elsewhere [30]. E. coli (MRE 600) tight-coupled $70 \mathrm{~S}$ ribosomes were obtained following the cell growth and harvesting procedures described previously [31]. Tight-coupled $70 \mathrm{~S}$ ribosomes were isolated as follows. Fifteen $\mathrm{g}$ of frozen $E$. coli cell paste was resuspended in $22.5 \mathrm{~mL}$ of buffer A (20 mM Tris- $\mathrm{HCl}, \mathrm{pH} 7.5,100 \mathrm{mM}$ $\mathrm{NH}_{4} \mathrm{Cl}, 10.5 \mathrm{mM}$ magnesium acetate, $0.5 \mathrm{mM}$ EDTA). After the addition of DNase I (8 $\mu$ g per $g$ of cell paste), the cells were disrupted in a French press. The disrupted cell slurry was then centrifuged for $1 \mathrm{~h}$ at 30,000 $\times g$. The supernatant was carefully removed, and then layered over a sucrose cushion of buffer B (1.1 M sucrose, $20 \mathrm{mM}$ Tris- $\mathrm{HCl}, \mathrm{pH} 7.5,0.5 \mathrm{M} \mathrm{KCl}, 10.5 \mathrm{mM}$ magnesium acetate, $0.5 \mathrm{mM}$ EDTA), and centrifuged at $45,000 \mathrm{rpm}$ in a $45 \mathrm{Ti}$ rotor for $17.5 \mathrm{~h}$. The ribosomal pellet was washed lightly in buffer $\mathrm{C}(1.5 \mathrm{M}$ ammonium sulfate, $10 \mathrm{mM}$ magnesium acetate, $400 \mathrm{mM} \mathrm{KCl}, 20$ $\mathrm{mM}$ Tris-Cl, pH 7.5) to remove any "skin" of cell debris, and resuspended in the same buffer. The ribosomal pellet was diluted in buffer $\mathrm{E}(10 \mathrm{mM}$ Tris- $\mathrm{HCl}, \mathrm{pH} 7.5$, $50 \mathrm{mM} \mathrm{KCl}, 60 \mathrm{mM} \mathrm{NH} \mathrm{Cl}_{4}, 10.5 \mathrm{mM}$ magnesium acetate, $0.25 \mathrm{mM}$ EDTA), pelleted overnight by centrifugation at 43,000 rpm in a 45Ti rotor, and resuspended in buffer E. The tight-coupled $70 S$ ribosomes were then separated from excess $50 \mathrm{~S}$ or $30 \mathrm{~S}$ subunits by ultracentrifugation with a gradient of $10 \%$ to $40 \%$ sucrose in buffer E. The tight-coupled $70 \mathrm{~S}$ ribosomes were diluted in buffer E without sucrose and pelleted as above.

\section{Limited Proteolysis of 705 Ribosomes}

Limited proteolysis using trypsin or Proteinase $\mathrm{K}$ was carried out in a buffer of $10 \mathrm{mM}$ Tris- $\mathrm{HCl}(\mathrm{pH} 7.7), 10$ $\mathrm{mM}$ magnesium acetate, $60 \mathrm{mM} \mathrm{NH}_{4} \mathrm{Cl}$, and $3 \mathrm{mM}$ $\beta$-mercaptoethanol at $37^{\circ} \mathrm{C}$. The enzyme to ribosome ratio was adjusted to $1: 500(\mathrm{wt} / \mathrm{wt})$ to achieve timeresolved cleavage with around $250 \mu \mathrm{g}$ of ribosome present initially. The ribosome concentration was determined by UV absorbance $\left(1 \mathrm{~A}_{260}\right.$ unit $=26 \mathrm{pmol}$ for $70 \mathrm{~S}$ [32] $).{ }^{\circ}$ The $^{\circ}$ total $^{\circ}$ reaction $^{\circ}$ mixture ${ }^{\circ}$ volume $^{\circ}$ was $^{\circ} 80^{\circ} \mu \mathrm{L}$. Aliquots were withdrawn from the reaction mixture at specified time intervals for electrophoretic and mass spectrometric analysis. For electrophoretic analysis, 1 $\mu \mathrm{L}$ of reaction mixture was removed, combined with the electrophoresis loading buffer and then immediately heated in a boiling water bath for $10 \mathrm{~min}$ to halt proteolysis. For MALDI analysis, $9 \mu \mathrm{L}$ of reaction mixture was removed and combined with $1 \mu \mathrm{L}$ of $25 \%$ trifluoroacetic acid (TFA) to quench the reaction. As controls, r-proteins isolated from 705 ribosomes by acetic acid treatment were resuspended in buffer $E$ and then incubated with trypsin, and 70S ribosomes were incubated without added protease. All control reactions 
were prepared for analysis by either electrophoresis or MALDI-MS as described above.

\section{Sucrose Density Gradient Centrifugation}

The integrity of ribosomal subunits was investigated by using a $0 \%$ to $45 \%$ sucrose gradient in a buffer containing $10 \mathrm{mM}$ Tris- $\mathrm{HCl}, \mathrm{pH} 7.5,10.5 \mathrm{mM}$ magnesium acetate, $60 \mathrm{mM} \mathrm{NH}_{4} \mathrm{Cl}$ and $3 \mathrm{mM}$ 2-mercaptoethanol. A $0 \%$ to $45 \%$ gradient was made by adding $36 \mathrm{~mL}$ of $22.5 \%$ solution of sucrose to polyallomer centrifuge tubes. Tubes were frozen at $-20^{\circ} \mathrm{C}$ overnight and thawed at $4{ }^{\circ} \mathrm{C}$. Samples after limited proteolysis were loaded on top of sucrose gradient and centrifuged at $19,000 \mathrm{rpm}$ for $17 \mathrm{~h}$ in an SW28 rotor with a Beckman XL-80 ultracentrifuge (Beckman Coulter, Palo Alto, CA) at $4{ }^{\circ} \mathrm{C}$. Sucrose gradients were fractionated using a density gradient fractionation system (ISCO Inc., Lincoln, NE). Fractions were collected and monitored at $260 \mathrm{~nm}$.

\section{SDS-PAGE and In-Gel Digestion}

Sodium dodecylsulfate polyacrylamide gels electrophoresis (SDS-PAGE) was carried out using 12.5\% polyacrylamide gels of 1-mm thickness, run at $250 \mathrm{~V}$ for 4 to $5 \mathrm{~h}$. The SDS-PAGE was visualized by staining with Coomassiegrilliant blue'R250. ${ }^{\circ}$ As necessary, ${ }^{\circ}$ excised ${ }^{\circ}$ gel bands ${ }^{\circ}$ were ${ }^{\circ}$ digested ${ }^{\circ}$ with ${ }^{\circ} \operatorname{trypsin}^{\circ}$ as $^{\circ}{ }^{\circ}$ escribed $[33]^{\circ}$ and analyzed by MALDI-MS.

\section{MALDI Analysis}

All MALDI-MS experiments were done on a Bruker Reflex IV reflectron MALDI time-of-flight mass spectrometer (Bruker Daltonics, Billerica, MA) equipped

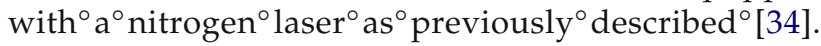
MALDI samples were prepared by combining $1 \mu \mathrm{L}$ of TFA-treated ribosomal solution with $9 \mu \mathrm{L}$ of the SA matrix. Protein mass spectra were obtained in the positive ion mode at an acceleration voltage of $20 \mathrm{kV}$, extraction voltage of $17.1 \mathrm{kV}$, and lens voltage of 10.1 $\mathrm{kV}$ by accumulating 300 laser shots. The laser power was adjusted to slightly above the threshold to obtain optimal resolution and signal-to-noise ratios. All samples were analyzed under identical instrumental parameters.

\section{Data Analysis}

Proteolytic digestion products were identified using the SequenceEditor software provided by the MALDI manufacturer ${ }^{\circ}$ and ${ }^{\circ}$ Protein ${ }^{\circ}$ Prospector ${ }^{\circ}[35]^{\circ} .{ }^{\circ}$ Images ${ }^{\circ}$ of the $30 S$ and $50 S$ subunit structures were produced using ${ }^{\circ} \mathrm{MacPyMol}^{\circ}[36]^{\circ}$ from ${ }^{\circ}$ the $3.5^{\circ} \mathrm{A}^{\circ} \mathrm{Crystal}^{\circ}$ structure $\mathrm{of}^{\circ} \mathrm{E}$. coli (accession $2 \mathrm{AVY} \mathrm{Y}^{\circ}$ and $\left.2 \mathrm{AW} 4\right)^{\circ}[17]^{\circ}$ and ${ }^{\circ}$ the 2.8 $\AA$ crystal structure of T. thermophilus (accession 2J00 and $\left.2 \mathrm{~J}^{\circ} 01\right)^{\circ}[18]$.

\section{Results and Discussion}

Several factors including protein-rRNA or proteinprotein interactions, location of proteins within the ribosome, protease:ribosome ratio, time of incubation, $\mathrm{pH}$, temperature, and protease specificity will influence the data obtained from limited proteolysis experiments; thus, optimization of a limited proteolysis strategy for intact ribosomes composed of over 50 proteins and several large RNAs requires examination of several experimental variables.

Initially, E. coli (strain MRE 600) tight-coupled $70 S$ ribosomes were subjected to time-course measurements of proteolysis employing a site-specific protease, trypsin, and a nonspecific protease, Proteinase $\mathrm{K}$, as described in the Experimental section. Optimization of the limited proteolysis conditions was carried out by varying the enzyme to ribosome ratio from 1:100 (wt/wt) to 1:2000 (wt/wt). MALDI-MS was used to analyze the proteolytic fragments and intact proteins from ribosomes. MALDI-MS data were compared with that obtained by SDS-PAGE as well as ${ }^{\circ}{ }^{\circ}$ data ${ }^{9}$ reported by $^{\circ}$ other techniques $[7,23,37]$ and, as necessary to confirm proteolytic fragment identities, in-gel digestion followed by MALDI peptide mass fingerprinting was also done. The results of these initial studies yielded an optimal enzyme to ribosome ratio of 1:500 (wt/wt) at $\mathrm{pH} 7.7$ and $37^{\circ} \mathrm{C}$, and these conditions were then used for all subsequent investigations. While the optimal enzyme to ribosome mole ratio of 1:5 is lower than typically seen in other limited proteolysis studies, it is not inconsistent $^{\circ}$ with $^{\circ}$ prior $^{\circ}$ literature $^{\circ}$ reports $^{\circ}\left[23,{ }^{\circ} 24\right]^{\circ}$ and, ${ }^{\circ}$ as discussed below, was found to provide sufficient information on surface accessible proteins while maintaining the overall organization of the ribosome and ribosomal subunits.

\section{Limited Proteolysis and Ribosome Integrity}

To confirm that the limited proteolysis conditions are appropriate to reveal information on the organization of 705 ribosomes and ribosomal subunits, a series of sucrose density gradient (SDG) centrifugation studies were conducted. The results of these studies are shown ${ }^{\circ}$ in $^{\circ}$ Figure $^{\circ} 1 .^{\circ}$ As $^{\circ}$ seen $^{\circ}$ here, ${ }^{\circ}$ limited $^{\circ}$ proteolysis does lead to dissociation of 705 ribosomes into the $30 \mathrm{~S}$ and $50 \mathrm{~S}$ subunits and that dissociation is complete within $500 \mathrm{~min}$ of incubation for both E. coli and $T$. thermophilus under the conditions used in this study. Significantly, even up to $1500 \mathrm{~min}$ of incubation, there is no loss to subunit organization as reflected by the presence of $30 \mathrm{~S}$ and $50 \mathrm{~S}$ subunits in these data. These results do show, however, that conclusions specific to the $70 \mathrm{~S}$ organization are limited to the first $60 \mathrm{~min}$ or less of incubation, and that data at $500 \mathrm{~min}$ and beyond are reporting on subunit organization only. 
(a)
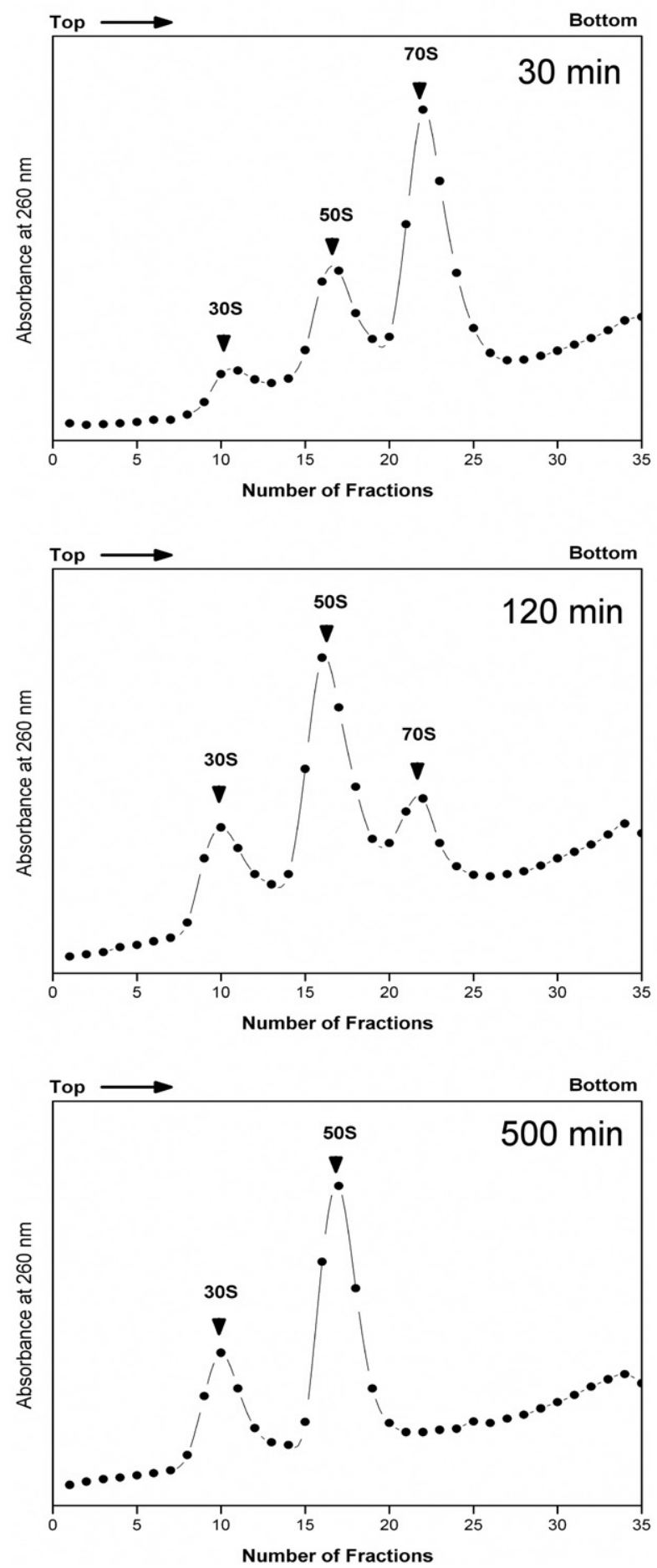

(b)
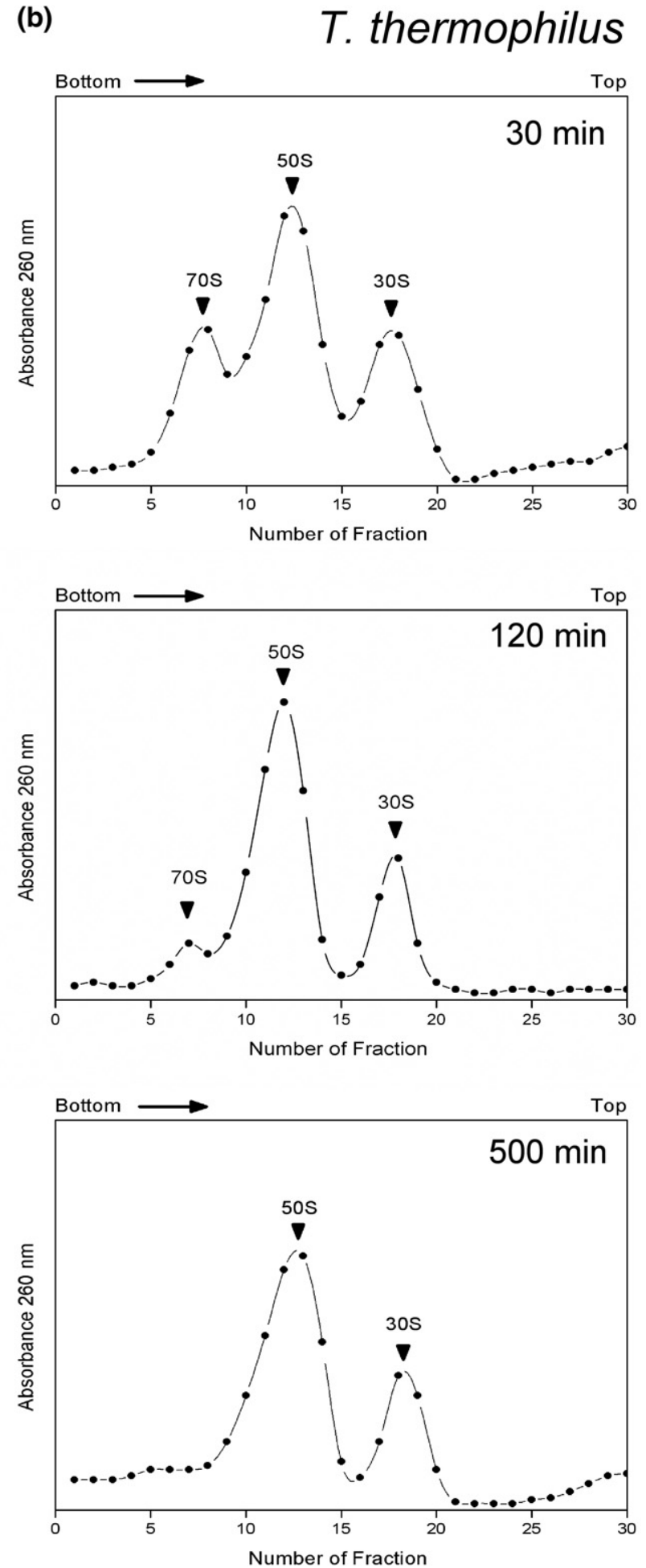

Figure 1. Sucrose density gradient centrifugation studies of intact E. coli and T. thermophilus $70 \mathrm{~S}$ ribosomes upon incubation with trypsin. For both organisms, the $70 \mathrm{~S}$ ribosomes begin dissociating within $30 \mathrm{~min}$ of incubation and have become completely dissociated by the $500 \mathrm{~min}$ incubation period.

\section{Limited Trypsin Proteolysis of E. coli $70 S$ Ribosomes}

Figure $^{\circ} 2^{\circ}$ shows $^{\circ} \mathrm{a}^{\circ}$ series $^{\circ}$ of $^{\circ}$ mass $^{\circ}$ spectra $^{\circ}$ from ${ }^{\circ}$ the limited proteolysis of E. coli $70 \mathrm{~S}$ ribosomes using trypsin. Intact proteins were assigned by accurate mass measurement of the ribosome mixture before proteolysis $(\mathrm{T}=0 \mathrm{~min}$ ) and by comparison to protein molecular weights predicted for $E$. coli from entries in the ${ }^{\circ}$ SwissProt ${ }^{\circ}$ database ${ }^{\circ}$ as $^{\circ}$ before $^{\circ}[34] .{ }^{\circ}{ }^{\circ}$ The ${ }^{\circ}$ r-proteins L2, L3, L6, L11, L13, L14, L15, L16, L17, L18, L20, L21, 
(a)

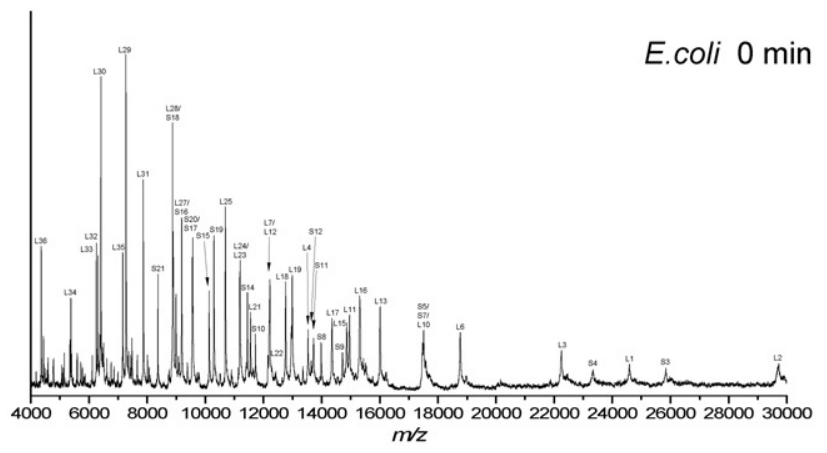

(b)

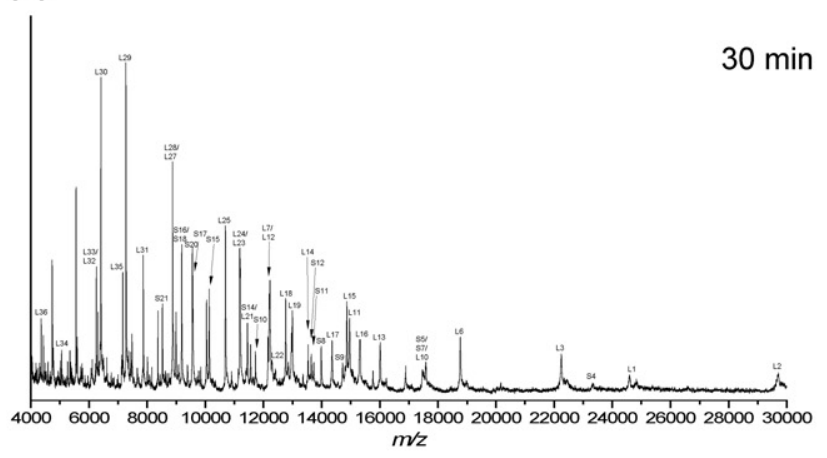

(c)

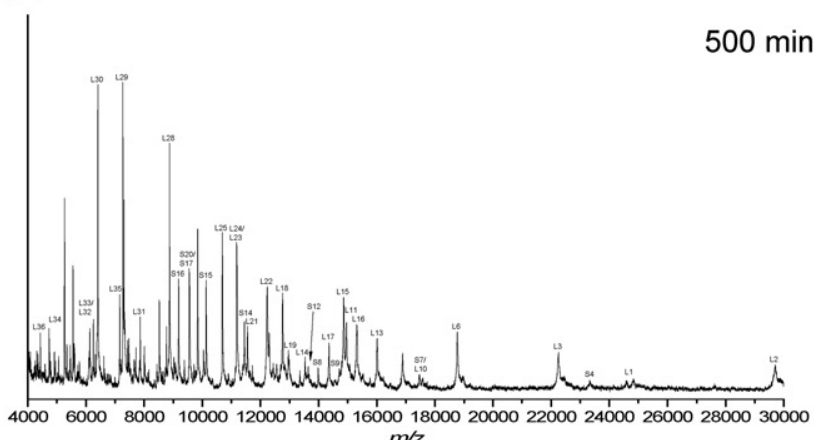

$m / z$

(d)

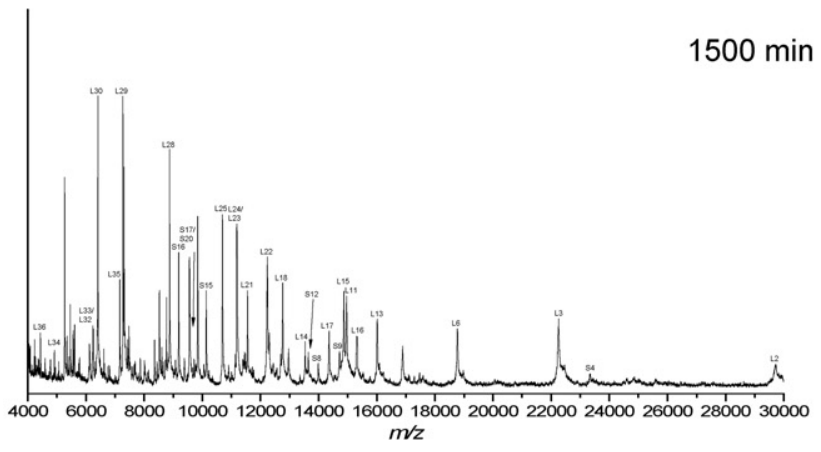

Figure 2. Representative $^{\circ} \mathrm{MALDI}^{\circ}$ mass $^{\circ}$ spectral $^{\circ}$ data $^{\circ}$ after incubation of intact $E$. coli $70 \mathrm{~S}$ ribosomes with trypsin under limited proteolysis conditions for the following time periods (a) $0 \mathrm{~min}$, (b) $30 \mathrm{~min}$, (c) $500 \mathrm{~min}$, and (d) $1500 \mathrm{~min}$. The intact ribosomal proteins detected after each incubation period are summarized ${ }^{\circ}{ }^{\circ}{ }^{\circ}$ Figure ${ }^{\circ} 3 .{ }^{\circ}$ Table $^{\circ} 1^{\circ}$ summarizes ${ }^{\circ}$ the ${ }^{\circ}$ identification of new $\mathrm{m} / \mathrm{z}$ values that arise during the limited proteolysis experiments.
L22, L23, L24, L25, L28, L29, L30, L32, L33, L34, L35, and L36 of the large subunit, and r-proteins S4, S8, S9, S12, S13, S15, S16, S17, and S20 of the small subunit were still detected as intact proteins even after incubation with trypsin for $1500 \mathrm{~min}$. After $1500 \mathrm{~min}$, an additional $0.5 \mu \mathrm{g}$ of trypsin was added to the reaction mixture and incubation was continued for $60 \mathrm{~min}$. Even under these conditions, no difference in the mass spectral results was seen compared with the data obtained at 1500 min (data not shown). The significantly greater number of large subunit compared with small subunit $r$-proteins that were resistant to limited proteolysis using trypsin is a reflection of the different organization and r-protein:rRNA mass $^{\circ}$ ratio $^{\circ}$ of ${ }^{\circ}$ the ${ }^{\circ}$ two $^{\circ}$ subunits ${ }^{\circ}\left[38,{ }^{\circ} 39\right] .^{\circ}$ The $^{\circ}$ mass spectral data limited to those proteins remaining intact after limited proteolysis with trypsin is summarized ${ }^{\circ}{ }^{\circ}{ }^{\circ}$ igure ${ }^{\circ}$.

In combination with the SDG data, there are three categories of r-proteins that do not remain intact throughout the entire incubation period examined in this study. In the first category are r-proteins S2, S3, S6, and S19, which were digested within 30 min under the conditions employed here as determined by the disappearance of mass spectral peaks corresponding to the mass of the intact protein. As the SDG studies revealed that the majority of the sample contains intact $70 \mathrm{~S}$ ribosomes at this incubation period, one can conclude that these ribosomal proteins are well-exposed on the ribosome surface or, at a minimum, have regions containing lysine(s) or arginine(s) that are sufficiently exposed for proteolysis. The second category contains r-proteins that are less stable to limited proteolysis with trypsin but whose original conformation, i.e., $70 \mathrm{~S}$ versus $30 S / 50 S$, cannot be determined by this experimental procedure. The r-proteins L7/L12, L27, S5, S11, and S18 were digested within $125 \mathrm{~min}$ under the conditions employed here. From the SDG studies, one can conclude that these proteins are susceptible to trypsin proteolysis either in their $\mathrm{ZOS}$ or subunit conformations, if not both. The final category contains r-proteins that are digested after $125 \mathrm{~min}$, here S7, S10, S14, S21, L1, L9, L10, L19, and L31. These data are likely reflecting subunit conformations as the SDG studies do not show intact $70 \mathrm{~S}$ ribosomes at these longer periods.

In addition to the loss of mass spectral peaks from specific intact r-proteins, new ion signals at various $\mathrm{m} / \mathrm{z}$ values were detected during these analyses. The mass spectral data of these new proteolytic fragments are summarized ${ }^{\circ}$ in $^{\circ}$ Table $^{\circ} 1 .^{\circ}$ The $^{\circ}$ new $^{\circ} \mathrm{m} / z$ values ${ }^{\circ}$ that ${ }^{\circ}$ arise during the limited proteolysis were identified, where possible, by combining knowledge of the specificity of trypsin with the mass values and original masses of the intact ${ }^{\circ} \mathrm{r}$-proteins. ${ }^{\circ} \mathrm{As}^{\circ}$ seen $^{\circ}$ in $^{\circ} \mathrm{Table}^{\circ} 1{ }^{\circ}$ the ${ }^{\circ}$ proteolytic fragments generally arise from cleavage of $\mathrm{N}$ - and/or C-terminal domains of the various r-proteins. Similar cleavages have been found during limited proteolysis studies of isolated r-proteins whose tertiary structure was $^{\circ}$ maintained $^{\circ}$ after $^{\circ}$ extraction $^{\circ}$ from $^{\circ}$ ribosomes $^{\circ}[40]$. 

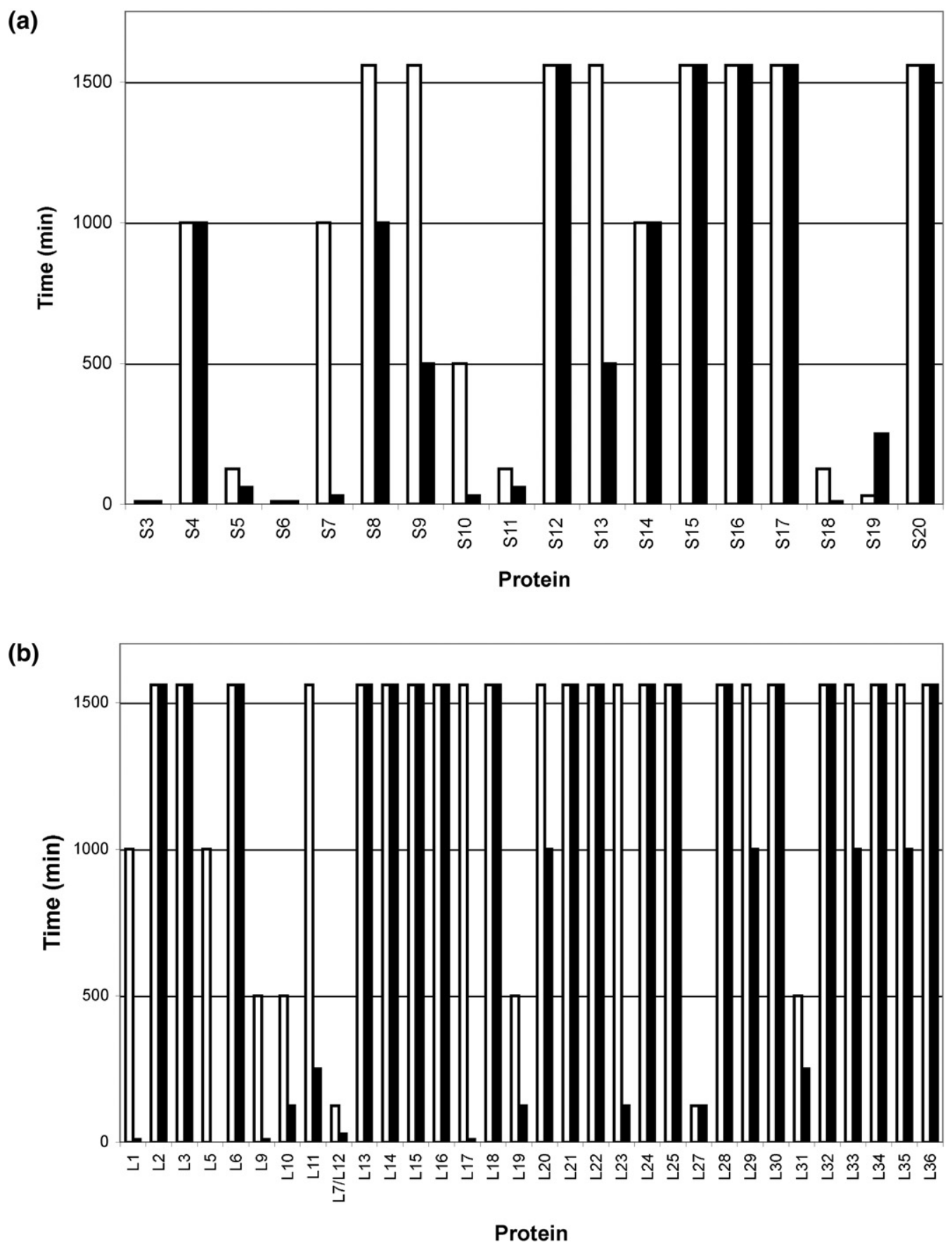

Figure 3. Intact E. coli ribosomal proteins from the (a) 30S subunit and (b) 50 S subunit observed with MALDI-MS after incubation with protease for denoted time periods; (white bars) trypsin and (black bars) Proteinase K.

These data demonstrate that direct MALDI-MS analysis of limited proteolysis mixtures is compatible with both the identification of proteins susceptible to enzymatic proteolysis as well as defining the sequence location of proteolysis.

To verify that the results obtained in these experiments reflected the organization of the ribosome, r-proteins were analyzed after incubating at $37^{\circ} \mathrm{C}$ for 1500 min without trypsin. No difference in the mass spectral data obtained under these conditions com- pared ${ }^{\circ}$ with ${ }^{\circ}$ the ${ }^{\circ} \mathrm{T}^{\circ}={ }^{\circ} 0^{\circ} \mathrm{min}^{\circ}$ data ${ }^{\circ}$ in ${ }^{\circ}$ Figure ${ }^{\circ} 2^{\circ}$ was ${ }^{\circ}$ found (data not shown). In addition, r-proteins that were isolated from the ribosome by acetic acid treatment were also resuspended in buffer and incubated with trypsin for $500 \mathrm{~min}$. MALDI-MS analysis of this reaction mixture yielded no intact proteins (data not shown). Under these conditions, r-proteins are separated from rRNA and the organizational structure of the ribosome is destroyed.

To confirm that the MALDI-MS data accurately 


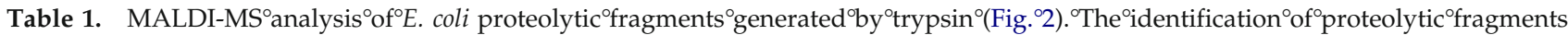
can occur even when $\mathrm{m} / \mathrm{z}$ values are detected for intact proteins, as seen here for ribosomal protein L2

\begin{tabular}{|c|c|c|c|c|c|}
\hline $\begin{array}{l}\text { Measured Mass } \\
\qquad[\mathrm{M}+\mathrm{H}]^{+}\end{array}$ & $\begin{array}{l}\text { Calculated Mass }^{a} \\
\qquad[\mathrm{M}+\mathrm{H}]^{+}\end{array}$ & $\Delta \mathrm{M}(\mathrm{Da})$ & Identity & Observed A.A. Residues & Loss of \\
\hline 4738.2 & 4738.4 & -0.2 & L7/L12 & $75-121$ & N-terminus \\
\hline 4752.6 & 4752.4 & 0.2 & L7/L12 & $75-121$ & $\mathrm{~N}$-terminus \\
\hline 5270.9 & 5271.2 & -0.3 & L31* & $1-47$ & C-terminus \\
\hline 5461.6 & 5461.4 & 0.2 & L9* & $1-50$ & C-terminus \\
\hline 5555.1 & 5555.5 & -0.4 & L31* & $1-49$ & C-terminus \\
\hline 5617.3 & 5617.6 & -0.3 & L9* & $1-51$ & C-terminus \\
\hline 5761.3 & 5760.8 & 0.5 & S14 & $48-97$ & $\mathrm{~N}$ - and C-termini \\
\hline 7128.4 & 7128.3 & 0.1 & L31 & $1-63$ & C-terminus \\
\hline 7315.7 & 7315.4 & 0.3 & S18* & $13-75$ & $\mathrm{~N}$-terminus \\
\hline 7339.1 & 7339.6 & -0.5 & L9 & $1-64$ & C-terminus \\
\hline 7721.5 & 7721.9 & -0.4 & $\mathrm{~S} 18$ & $10-75$ & N-terminus \\
\hline 8162.6 & 8162.5 & 0.1 & S18 & 7-75 & $\mathrm{N}$-terminus \\
\hline 8357.9 & 8358.6 & -0.7 & L10* & $62-138$ & $\mathrm{~N}$ - and $\mathrm{C}$-termini \\
\hline 8529.9 & 8529.8 & 0.1 & L27* & 6-85 & $\mathrm{N}$-terminus \\
\hline 8629.1 & 8629.0 & 0.1 & $\mathrm{~S} 18$ & $4-75$ & $\mathrm{~N}$-terminus \\
\hline 8658.1 & 8658.0 & 0.1 & $\mathrm{~L} 27$ & $5-85$ & $\mathrm{~N}$-terminus \\
\hline 8768.8 & 8768.2 & 0.6 & S6 & $39-112$ & $\mathrm{~N}$ - and $\mathrm{C}$-termini \\
\hline 8870.7 & 8870.3 & 0.4 & S3 & $2-79$ & C-terminus \\
\hline 9715.9 & 9715.4 & 0.5 & S19* & $2-87$ & C-terminus \\
\hline 9844.9 & 9843.6 & 0.3 & S19* & $2-88$ & C-terminus \\
\hline 10043.6 & 10043.8 & -0.2 & S19 & $2-90$ & C-terminus \\
\hline 12310.6 & 12311.1 & -0.5 & $\mathrm{~S} 11^{*}$ & $10-125 / 11-126 / 12-127 / 14-129$ & $\mathrm{~N}$-and C-termini \\
\hline 12248.5 & 12249.2 & 0.7 & L19* & $2-109$ & C-terminus \\
\hline 12566.1 & 12566.4 & -0.3 & $\mathrm{~S} 11$ & $12-129$ & $\mathrm{~N}$ - and $\mathrm{C}$-termini \\
\hline 12861.2 & 12861.9 & -0.7 & S6 & $3-112$ & $\mathrm{~N}$ - and $\mathrm{C}$-termini \\
\hline 16225.1 & 16225.8 & -0.7 & S7 & $12-156$ & $\mathrm{~N}$-terminus \\
\hline 16895.1 & 16894.6 & 0.5 & $\mathrm{~S} 5 *$ & $7-167$ & N-terminus \\
\hline 24842.3 & 24843.0 & -0.7 & $\mathrm{~S} 3^{*}$ & $2-225$ & C-terminus \\
\hline 27597.6 & 27599.9 & -2.3 & $\mathrm{~L} 2 *$ & $2-256$ & C-terminus \\
\hline
\end{tabular}

*Protein fragments were still detected after 1500 min incubation with trypsin.

aThe average singly protonated mass of the tryptic products is shown as calculated using SequenceEditor ver. 1.0, provided by Bruker Daltonics and ProteinProspector.

reflect the limited proteolysis of ribosomes, SDSPAGE analysis was also done on the trypsin incubated ribosomes. In agreement with the MALDI-MS results, some protein bands do not decrease in intensity with time while other proteins are no longer detected on the gel (data not shown). Unlike the MALDI-MS results, specific lower molecular weight r-proteins are difficult to identify on the 1-D gel due to the poor resolution of this approach. However, the higher molecular weight proteins are easily monitored by 1-D PAGE and the response of these higher molecular weight proteins agrees with the response found by MALDI analysis.

\section{Limited Proteinase K Proteolysis of E. coli $70 S$ Ribosomes}

In a manner similar to the above-described experiments with trypsin, E. coli $70 S$ ribosomes were incubated with the nonspecific protease, Proteinase K. In contrast to trypsin, which will only cleave at lysine or arginine residues, Proteinase K cleaves at any aromatic, aliphatic, or hydrophobic amino acid residue. Thus, Proteinase K should provide a more general picture of exposed pro- teins within the ribosome compared with trypsin. In addition, comparative proteolysis can be used to distinguish topological features that are specifically trypsin resistant, such as L7/L12, whose conformation is trypsin resistant ${ }^{\circ}$ in ${ }^{\circ}$ the ${ }^{\circ}$ absence ${ }^{\circ}$ of ${ }^{\circ}$ elongation ${ }^{\circ}$ factor ${ }^{\circ} G^{\circ}(E F-G)^{\circ}[22]$.

Figure S1 (which can be found in the electronic version of this article) shows the mass spectrum of r-proteins remaining from the limited proteolysis of $70 \mathrm{~S}$ ribosome using ${ }^{\circ}$ Proteinase ${ }^{\circ}{ }^{\circ}$ for $1500{ }^{\circ} \mathrm{min}$. Figure ${ }^{\circ}{ }^{\circ}$ summarizes the data from these MALDI experiments. The use of Proteinase $\mathrm{K}$ revealed a number of r-proteins that are rapidly digested upon limited proteolysis. Within the large subunit, r-proteins L1, L7/12, L9, and L17 are digested within the first $30 \mathrm{~min}$ of incubation. These results are in general agreement with those reported previously from limited proteolysis ${ }^{\circ}$ experiments ${ }^{\circ}{ }^{\circ}{ }^{\circ} 50 S^{\circ}$ subunits ${ }^{\circ}[23] .{ }^{\circ}$ In addition, the small subunit r-proteins S2, S3, S6, S7, S10, S18, and S21 are digested within the first $30 \mathrm{~min}$ and S5 and S11 are digested within the first $60 \mathrm{~min}$ of incubation. The r-proteins L7/L12, L9, L17, S7, S18, and S21 were found to be well exposed and S2, S3, and S6 were found to be moderately exposed on intact ribosomes during hot tritium bombardment ${ }^{\circ}$ experiments [8]. Interestingly, ${ }^{\circ} 4$, , S20, L16, and L24 were also proposed to be well-exposed by 
tritium quantification yet are significantly stable to proteolysis by Proteinase K suggesting differences in conformations between the two studies or differences in reactivity to proteolysis and tritium incorporation for these particular proteins.

As was done in the incubations with trypsin, a Coomassie blue-stained PAGE analysis of several ribosome incubations was done for comparison (Figure S2). Similar trends are observed between the MALDI-MS data and the 1-D PAGE data: various proteins are observed to decrease in intensity with increased incubation with Proteinase $\mathrm{K}$ and new bands, presumed to be proteolytic fragments, are also detected. To identify several of the new bands generated during limited proteolysis that occurred at higher molecular weights, in-gel tryptic digestion and MALDI peptide mass fingerprinting for protein identification was done. As a representative example, a new band (circled in Figure S2) appearing at a lower molecular weight than the band for intact ribosomal protein L2 (band B, Figure S2) was detected in lane 8, which corresponds to a $1500 \mathrm{~min}$ incubation with Proteinase K. In-gel digestion and MALDI peptide mass fingerprinting yielded a match to ribosomal protein L2. Similar analyses were done on other bands, which are denoted in Figure S2. Table S1 summarizes the in-gel digestion and MALDI peptide mass fingerprinting results from the annotated bands from Figure S2. In addition to the lack of resolution at lower molecular weights for this 1-D gel, another obvious disadvantage of an electrophoretic-based approach is the need to perform additional identifications of new bands.

While these new bands could be identified by in-gel tryptic ${ }^{\circ}$ digestion ${ }^{\circ}$ and ${ }^{\circ} \mathrm{MALDI}^{\circ}$ peptide ${ }^{\circ}$ mass $^{\circ}$ fingerprinting, the use of a nonspecific protease hinders determination of precise sites of proteolysis. Most significant, though, is the correlation between MALDI and PAGE results as well as the correlation between r-protein stability and limited proteolysis with the two enzymes. By comparison of the limited proteolysis results obtained between trypsin and Proteinase K, the r-proteins whose surface exposed regions are resistant to trypsin but not general proteolysis can be identified.

\section{Comparison of E. coli MALDI-MS Data Obtained from Different Proteases}

The E. coli r-proteins S12, S15, S16, S17, S20, L2, L3, L6, L13, L14, L15, L16, L18, L21, L22, L24, L25, L28, L30, L32, L34, and L36 were not completely digested by either trypsin or Proteinase $\mathrm{K}$ even at the longest periods of incubation $(1500 \mathrm{~min}$ or $1500+60 \mathrm{~min}$, respectively) examined in these studies. The r-proteins, L20, L29, L33, L35, S4, and S8, which were detected intact after the 1000 min incubation with Proteinase K but not trypsin, were eventually digested by Proteinase $\mathrm{K}$ after longer incubation periods. Thus, the trends for protein stability were similar for the two proteases used in this study with less r-proteins being stable when incubated with the non-specific protease. The use of the less specific protease, Proteinase $\mathrm{K}$, resulted in 11 more completely digested proteins compared with trypsin. Such results are to be expected, given the lack of specificity for Proteinase K. However, because interactions between r-proteins and rRNA are usually through salt-bridges between positively charged residues on the proteins ${ }^{\circ}$ and phosphate $^{\circ}$ oxygen ${ }^{\circ}$ atoms ${ }^{\circ}$ on the RNA [41], basic residues such as arginine and lysine that interact with rRNA through salt-bridges will be less susceptible to ${ }^{\circ}$ proteolysis. ${ }^{\circ}$ Thus, ${ }^{\circ}$ protease ${ }^{\circ}$ specificity $^{\circ}$ may $^{\circ}$ not $^{\circ}$ account for all of the differences between trypsin and Proteinase $\mathrm{K}$ found in this study, although an examination of the data obtained in this study did not discern any relationship between the frequency of Arg/Lys residues within a protein and the rate of proteolysis with trypsin.

\section{Limited Proteolysis of T. thermophilus $70 S$ Ribosomes}

In a manner similar to that just described, limited proteolysis studies were also conducted on T. thermophilus (Figure ${ }^{\circ} 4^{\circ}$ and $^{\circ}$ Figure $^{\circ}$ S3).$^{\circ}$ Intact $^{\circ}$ proteins $^{\circ}$ were assigned by accurate mass measurement of the ribosome mixture before proteolysis $(\mathrm{T}=0 \mathrm{~min})$ and by comparison to protein molecular weights predicted for T. thermophilus HB8 from entries in the SwissProt database $^{\circ}$ as $^{\circ}$ before $^{\circ}[42] .{ }^{\circ}$ The $^{\circ}$ r-proteins ${ }^{\circ} \mathrm{L} 1,{ }^{\circ} \mathrm{L} 2,{ }^{\circ} \mathrm{L} 3,{ }^{\circ} \mathrm{L} 6,{ }^{\circ} \mathrm{L} 13$, L14, L15, L16, L17, L18, L20, L21, L22, L23, L24, L28, L29, L30, L32, L33, L34, L35, and L36 of the large subunit, ${ }^{\circ}$ and $^{\circ}{ }^{\circ} \mathrm{r}$-proteins ${ }^{\circ} \mathrm{SThx},{ }^{\circ} \mathrm{S} 6,{ }^{\circ} \mathrm{S} 8,{ }^{\circ} \mathrm{S} 9,{ }^{\circ} \mathrm{S} 10,{ }^{\circ} \mathrm{S} 14,{ }^{\circ} \mathrm{S} 15$, and S17 of the small subunit were still detected as intact proteins even after incubation with either trypsin or Proteinase $\mathrm{K}$ for $1500 \mathrm{~min}$. The mass spectral data limited to those proteins remaining intact after limited proteolysis ${ }^{\circ}$ are $^{\circ}$ summarized $^{\circ}$ in $^{\circ}$ Figure $^{\circ} 5^{\circ}$ and ${ }^{\circ}$ Figure $^{\circ} \mathrm{S} 4$.

The r-proteins S3, S12, S16, S18, S19, and L19 were digested within $10 \mathrm{~min}$ under the conditions employed here as determined by the disappearance of mass spectral peaks corresponding to the mass of the intact protein. The SDG studies revealed that the majority of the sample contains intact 705 ribosomes at this incubation period, thus we conclude that these ribosomal proteins are well-exposed on the ribosome surface or, at a minimum, have regions containing lysine(s) or arginine(s) that are sufficiently exposed for proteolysis. Similarly, r-proteins L12, L19, L25, L31, S3, S5, S7, S12, S18, and S19 were digested within 60 min upon incubation with Proteinase K.

In addition to the loss of mass spectral peaks from these r-proteins, new ion signals at various $m / z$ values were detected during these analyses. The mass spectral data of the tryptic fragments of $T$. thermophilus are summarized ${ }^{\circ}$ in $^{\circ}$ Table $^{\circ} 2 .{ }^{\circ}$ The $^{\circ}$ new $^{\circ} \mathrm{m} / z$ values ${ }^{\circ}$ that ${ }^{\circ}$ arise during the limited proteolysis were identified, where possible, by combining knowledge of the specificity of trypsin with the mass values and original masses of the 
(a)

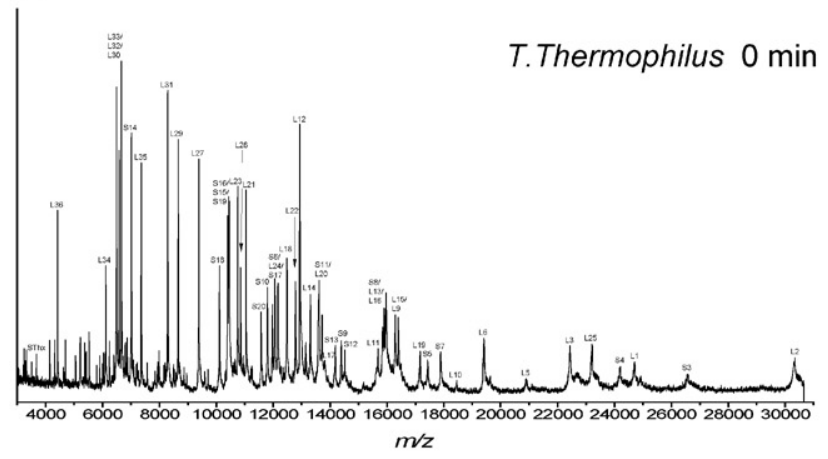

(b)

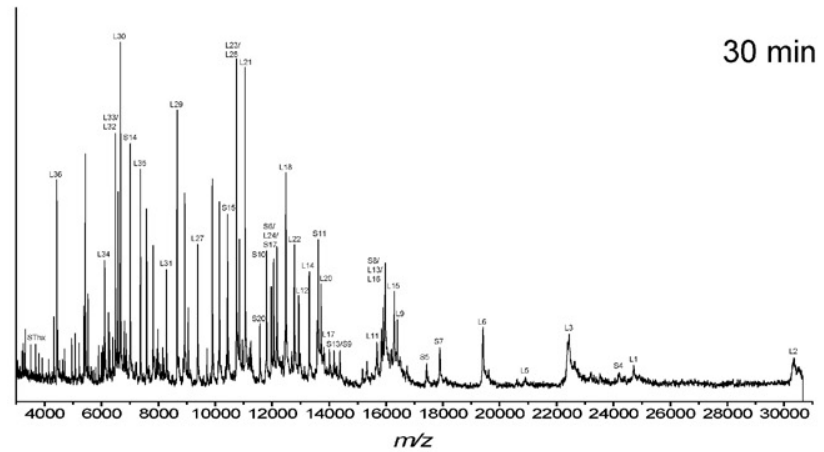

(c)

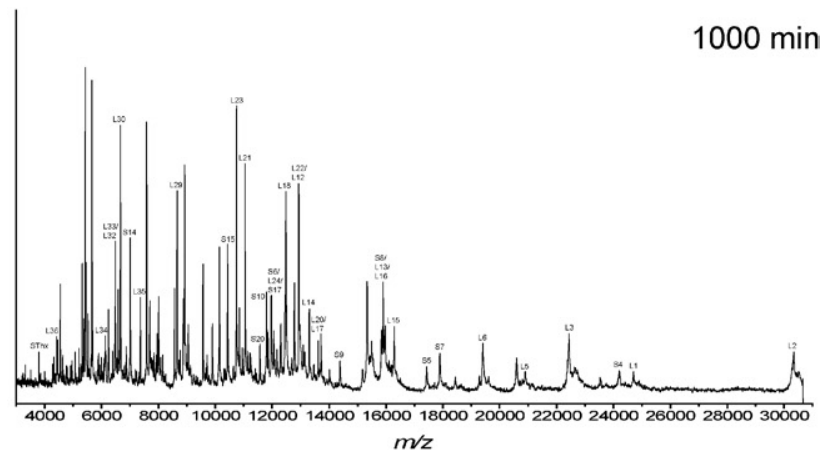

(d)

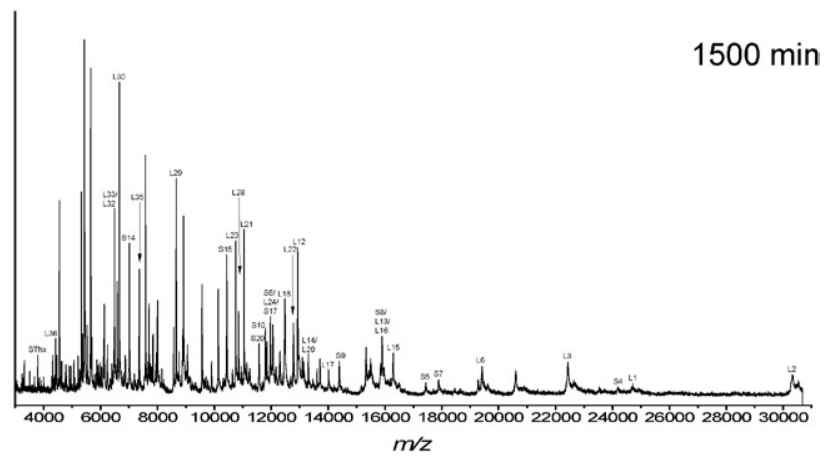

Figure 4. Representative MALDI mass spectral data after incubation of intact $T$. thermophilus $70 \mathrm{~S}$ ribosomes with trypsin under limited proteolysis conditions for the following time periods (a) 0 min, (b) $30 \mathrm{~min}$, (c) $500 \mathrm{~min}$, and (d) $1500 \mathrm{~min}$. The intact ribosomal proteins detected after each incubation period are summarized $^{\circ}$ in ${ }^{\circ}$ Figure ${ }^{\circ} 5^{\circ}$ and ${ }^{\circ}$ Figure $^{\circ} S 4 .{ }^{\circ}$ Table $^{\circ} 2^{\circ}$ summarizes ${ }^{\circ}$ the identification of new $\mathrm{m} / \mathrm{z}$ values that arise during the limited proteolysis experiments. intact $^{\circ}$ r-proteins. ${ }^{\circ} \mathrm{As}^{\circ}$ seen $^{\circ}$ in $^{\circ}$ Table $^{\circ} 2,^{\circ}$ the ${ }^{\circ}$ proteolytic fragments generally arise from cleavage of $\mathrm{N}$ - and/or C-terminal domains of the various r-proteins.

\section{Comparison of E. coli and T. thermophilus Limited Proteolysis Data}

Figure ${ }^{\circ} 5^{\circ}$ summarizes $^{\circ}$ the ${ }^{\circ}$ trypsin ${ }^{\circ}$ limited $^{\circ}$ proteolysis mass spectral data obtained in this study. As noted in this figure, there is generally good agreement between the limited proteolysis results found for E. coli and $T$. thermophilus, thus the method developed here reports on the structure of (bacterial) ribosomes. As discussed above, most r-proteins for both organisms are detected intact even after long periods of incubation with trypsin or Proteinase $\mathrm{K}$ and likely demonstrate no conformational changes upon dissociation of intact $70 \mathrm{~S}$ ribosomes into the small and large subunits.

A few r-proteins, S3, S11, S18, S19, and L27, were readily digested (within $30 \mathrm{~min}$ ) for both organisms suggesting similarities in trypsin susceptibility within the 70S structure. The tryptic peptide S3 (2-79) was detected in both organisms. S3 has been found to contain basic residues which protrude into the upstream ${ }^{\circ}$ tunnel ${ }^{\circ}$ of ${ }^{\circ}$ the ${ }^{\circ}$ entry ${ }^{\circ}$ pore ${ }^{\circ}$ for ${ }^{\circ}$ the ${ }^{\circ} \mathrm{mRNA}{ }^{\circ}[43]^{\circ}$. S11 and S18 are believed to have extensive contacts with S1 [43], ${ }^{\circ}$ which ${ }^{\circ}$ was $^{\circ}$ lost $^{\circ}$ in ${ }^{\circ}$ the ${ }^{\circ}$ ribosome ${ }^{\circ}$ preparations ${ }^{\circ}$ used in this work, possibly accounting for their limited stability here. The C-terminus of S19 was digested with trypsin in these studies. This terminus points toward the interface side of $30 \mathrm{~S}$ and this region was found disordered ${ }^{\circ}$ in $^{\circ}$ the ${ }^{\circ} T$. thermophilus $30 \mathrm{~S}^{\circ}$ structure $^{\circ}[37]$. $^{\circ} 27$ is found to interact within the P site and S11 within the

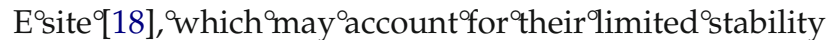
in this work as the ribosomes investigated did not have occupied A, P, or E sites.

Among the r-proteins that were found to be particularly susceptible to trypsin, a larger number were unique to the particular organism being studied. For $E$. coli, S5, S6, S10, and L12 were significantly less stable than their T. thermophilus counterparts. Similarly, for $T$. thermophilus, S12, S13, S16, L11, L19, L25, and L31 were significantly less stable than their E. coli counterparts. Within this group, all proteins except L31 have longer C-termini tails than found in E. coli. These extended regions tend to be basic and solvent-exposed, likely leading to the difference in results seen between $T$. thermophilus and E. coli, and L31 has recently been remodeled on the $2.8 \AA 70 \mathrm{~S}$ bacterial crystal structure into a position that is consistent with the ease it dissociates ${ }^{\circ}$ from ${ }^{\circ}$ the ${ }^{\circ}$ ribosome ${ }^{\circ}[18]$.

\section{Comparison with Other Biophysical Information}

Those proteins readily hydrolyzed in both cases should be surface accessible, thus providing information on the ribosome topography. The positions of the r-proteins 

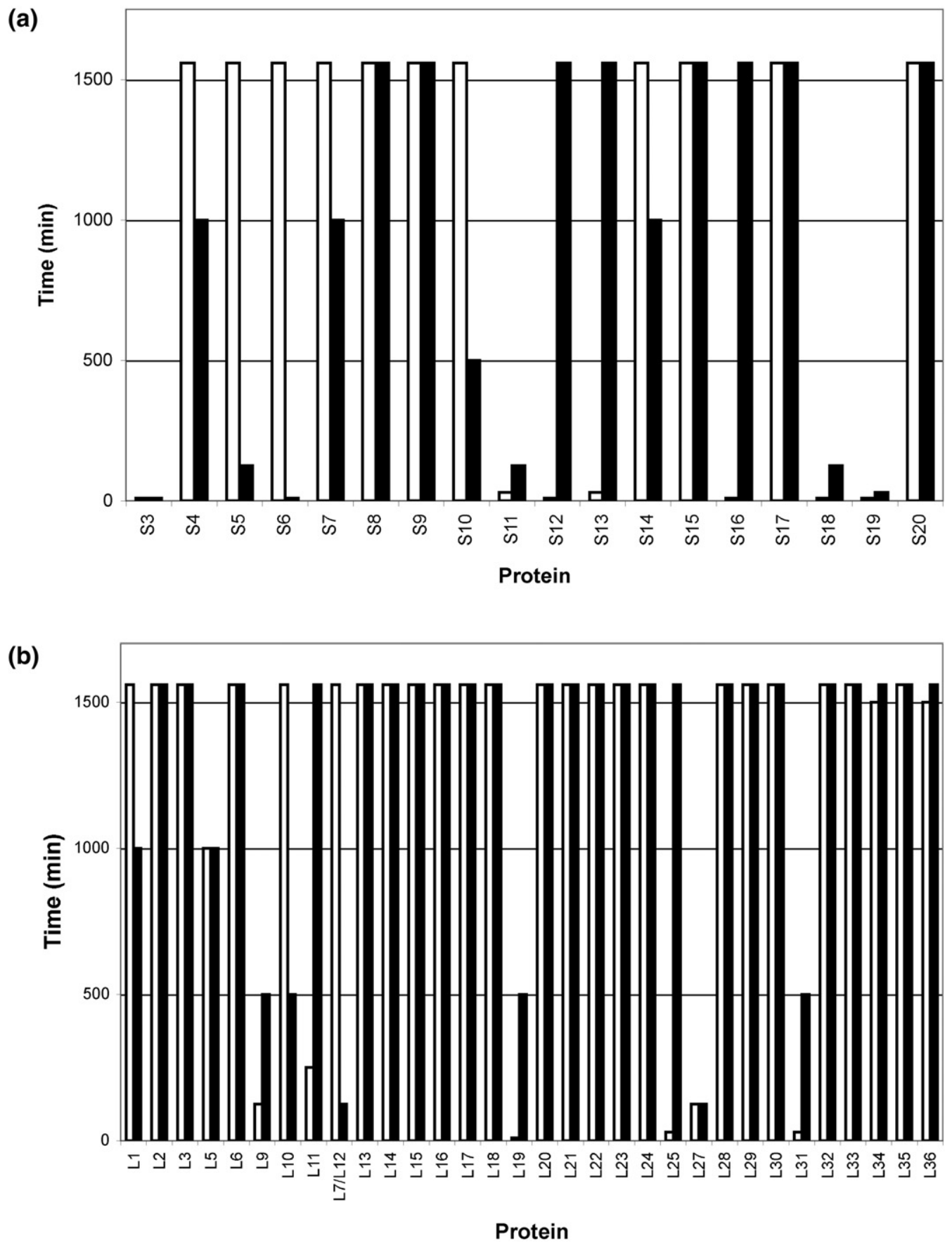

Figure 5. Intact ribosomal proteins from the (a) $30 \mathrm{~S}$ subunit and (b) $50 \mathrm{~S}$ subunit observed with MALDI-MS after incubation with trypsin for denoted time periods; (white bars) T. thermophilus and (black bars) E. coli.

from the $30 \mathrm{~S}$ and $50 \mathrm{~S}$ subunits found to be readily digested by both trypsin and Proteinase K are shown on the ${ }^{\circ}$ E. coli $70 \mathrm{~S}^{\circ} 3.5^{\circ} \AA^{\circ} \mathrm{Crystal}^{\circ}$ structure ${ }^{\circ}[17]^{\circ}$ and ${ }^{\circ}$ on ${ }^{\circ}$ the ${ }^{\circ} \mathrm{T}$. thermophilus $2.8^{\circ} \AA^{\circ}$ crystal $^{\circ}$ structure $[18]^{\circ}{ }^{\circ}{ }^{\circ}$ Figure ${ }^{\circ} 6$. The crystal structures used here do not contain coordinates for r-proteins S1, L7/L12, L10, L11 (T. thermophilus only), L36 (T. thermophilus only), and L28 (E. coli only). Although coordinates for L10 and L12 are not available, these proteins were found to be susceptible to limited proteolysis $^{\circ}$ in $^{\circ}$ this $^{\circ}$ study. $^{\circ}$ As $^{\circ}$ seen $^{\circ}$ in $^{\circ}$ Figure $^{\circ} 6,{ }^{\circ}$ the majority of unstable r-proteins are within the $30 \mathrm{~S}$ subunit, specifically in the head and platform regions. Such results are not surprising as these regions were found to be more disordered in earlier X-ray structures, which hindered ${ }^{\circ}$ assignment ${ }^{\circ}$ of $^{\circ}$ specific ${ }^{\circ}$ ribosomal $^{\circ}$ proteins ${ }^{\circ}[7$, $23,37]$. The $50 S^{\circ}$ subunit and ${ }^{\circ}$ the ${ }^{\circ}$ ody ${ }^{\circ}$ of the $305^{\circ}$ subunit contain significantly fewer r-proteins susceptible to limited proteolysis. Similar information is presented in Figure S5, which places those r-proteins likely to be susceptible to proteolytic digestion within the 70S ribo- 
Table 2. MALDI-MS ${ }^{\circ}$ analysis ${ }^{\circ} \mathrm{of}^{\circ} \mathrm{T}$. thermophilus proteolytic ${ }^{\circ}$ fragments $^{\circ}$ generated $^{\circ}$ by $^{\circ}$ trypsin ${ }^{\circ}\left(\right.$ Figure $\left.^{\circ} 4\right)$

\begin{tabular}{|c|c|c|c|c|c|}
\hline $\begin{array}{l}\text { Measured Mass } \\
\qquad[\mathrm{M}+\mathrm{H}]^{+}\end{array}$ & $\begin{array}{l}\text { Calculated Mass }^{\mathrm{a}} \\
\qquad[\mathrm{M}+\mathrm{H}]^{+}\end{array}$ & $\begin{array}{r}\Delta \mathrm{M} \\
(\mathrm{Da})\end{array}$ & Identity & Observed A.A. Residues & Loss of \\
\hline 4552.4 & 4552.3 & 0.1 & L19* & $1-39$ & C-terminus \\
\hline 5321.6 & 5321.3 & 0.3 & $\mathrm{~L} 14^{* \mathrm{bc}}$ & $1-49$ & C-terminus \\
\hline 5426.5 & 5426.4 & 0.1 & L31* & $1-48$ & C-terminus \\
\hline 5449.9 & 5449.5 & 0.4 & L9* & $1-50$ & $\mathrm{~N}$-terminus \\
\hline 5653.6 & 5653.5 & 0.1 & $\mathrm{~L} 12 * \mathrm{c}$ & $2-57$ & C-terminus \\
\hline 6116.9 & 6117.3 & -0.4 & L9 & $1-56$ & C-terminus \\
\hline 6127.4 & 6127.2 & 0.2 & L25 & $20-72$ & $\mathrm{~N}$ - and $\mathrm{C}$-terminus \\
\hline 7582.5 & 7582.1 & 0.4 & S18* & $24-88$ & $\mathrm{~N}$-terminus \\
\hline 7809.6 & 7809.4 & 0.2 & $\mathrm{~S} 18$ & $22-88$ & N-terminus \\
\hline 8880.0 & 8879.3 & 0.7 & S3* & $2-79$ & C-terminus \\
\hline 8913.8 & 8913.3 & 0.5 & L27* & $6-85$ & $\mathrm{~N}$-terminus \\
\hline 9042.0 & 9041.5 & 0.5 & L27 & $5-85$ & $\mathrm{~N}$-terminus \\
\hline 9565.9 & 9565.2 & 0.7 & S19* & $2-85$ & C-terminus \\
\hline 9674.5 & 9674.3 & 0.2 & L9 & $62-148$ & N-terminus \\
\hline 9893.9 & 9894.6 & -0.7 & S19 & $2-88$ & C-terminus \\
\hline 10143.4 & 10143.9 & -0.5 & L9 & $58-148$ & N-terminus \\
\hline 10299.6 & 10300.1 & -0.5 & L9 & $57-148$ & N-terminus \\
\hline 10130.0 & 10130.8 & -0.8 & $\mathrm{~S} 16^{*}$ & $1-85$ & C-terminus \\
\hline 11144.2 & 11144.1 & 0.1 & S13* & $2-99$ & C-terminus \\
\hline 11852.6 & 11853.2 & -0.6 & $\mathrm{~S} 17^{* \mathrm{c}}$ & $2-101$ & C-terminus \\
\hline 12303.7 & 12303.1 & 0.6 & $\mathrm{~S} 11 *$ & $13-129$ & $\mathrm{~N}$-terminus \\
\hline 12459.6 & 12459.3 & 0.3 & $\mathrm{~S} 11$ & $12-129$ & $\mathrm{~N}$-terminus \\
\hline 12686.5 & 12686.6 & -0.1 & S11 & $10-129$ & $\mathrm{~N}$-terminus \\
\hline 13092.7 & 13092.3 & 0.4 & L19* & $1-111$ & C-terminus \\
\hline 13465.2 & 13465.8 & -0.6 & S13* & $2-120$ & C-terminus \\
\hline 13593.1 & 13593.9 & -0.8 & $\mathrm{~S} 13$ & $2-121$ & C-terminus \\
\hline 14015.3 & 14015.7 & -0.4 & $\mathrm{~S} 12^{*}$ & $2-127$ & C-terminus \\
\hline 14272.2 & 14272.8 & -0.6 & L19 & $1-120$ & C-terminus \\
\hline 15336.0 & 15335.1 & 0.9 & $\mathrm{~L} 16^{* \mathrm{c}}$ & $6-141$ & $\mathrm{~N}$-terminus \\
\hline 18442.5 & 18441.3 & 1.2 & $\mathrm{~L} 1 * \mathrm{c}$ & 20-191 & $\mathrm{N}$ - and $\mathrm{C}$-terminus \\
\hline 20594.5 & 20595.9 & -1.4 & $\mathrm{~L} 25^{*}$ & 1-182 & C-terminus \\
\hline
\end{tabular}

*Protein fragments were still detected after 1500 min incubation with trypsin

${ }^{a}$ The average singly protonated mass of the tryptic products is shown as calculated using SequenceEditor ver. 1.0, provided by Bruker Daltonics and ProteinProspector.

bThe ion at $\mathrm{m} / \mathrm{z} 5321$ can be generated from $\mathrm{L} 2$ (168-216, $\mathrm{m} / \mathrm{z} 5321.1)$ and L14 (1-49, $\mathrm{m} / \mathrm{z} 5321.3)$. Although these cannot be differentiated at the mass accuracy available here, it is noted that the ion abundance of intact L14 but not L2 decreases with increasing incubation with trypsin.

${ }^{\mathrm{C}}$ Intact proteins also detected.

some surface for clarity. The similarities between the proteolytic digestion of $30 \mathrm{~S}$ head and platform proteins from $E$. coli and $T$. thermophilus are readily recognized.

Recently, Yamamoto and coworkers utilized MALDI-MS in combination with $\mathrm{H} / \mathrm{D}$ exchange to probe the flexibility of ${ }^{\circ}$ E. coli $70 S^{\circ}$ ribosomes $^{\circ}[10]^{\circ}{ }^{\circ}$ They $^{\circ}$ concluded $^{\circ}$ that ${ }^{\circ}$ the extent of deuterium incorporation is closely related to the $30 \mathrm{~S}$ and $50 \mathrm{~S}$ assembly processes, with highly deuterated proteins being incorporated late in the assembly process. Because that $H / D$ exchange approach as well as the approach developed here should probe ribosome topology, it is of interest to note that these limited proteolysis results are only marginal related to assembly order. For example, r-proteins L6, L14, L16, L19, L25, L27, L28, L30, L31, and L32 are incorporated late in the assembly process of $^{\circ}$ the ${ }^{\circ} 505^{\circ}$ subunit $^{\circ}\left[44,{ }^{\circ} 45\right]{ }^{\circ}{ }^{\circ}$ Within ${ }^{\circ}$ this ${ }^{\circ}$ list, ${ }^{\circ}$ only ${ }^{\circ}$ L19, ${ }^{\circ} \mathrm{L} 27$, and L31 were found to be particularly susceptible to limited proteolysis with either protease. Moreover, each of these three r-proteins yielded stable tryptic fragments that were detectable even after $1500 \mathrm{~min}$ incubation with trypsin'(Table 1 ). 9 More relevant than the assembly process is the surface accessibility of these proteins as seen in
Figure $\%$. Within ${ }^{9}$ the ${ }^{\circ}$ small ${ }^{\circ}$ subunit, ${ }^{9}$ the ${ }^{9}$-proteins ${ }^{\circ}$ incorporated late in the assembly process include $\mathrm{S} 2, \mathrm{~S} 3, \mathrm{~S} 10, \mathrm{~S} 14$, and ${ }^{\circ} 21{ }^{\circ}[46,47]^{\circ}{ }^{\circ}$ All ${ }^{\circ}$ except $^{\circ} S 14^{\circ}{ }^{\circ}$ are ${ }^{\circ}$ readily ${ }^{\circ}$ digested, but $^{\circ}$ in addition it was also found that S5, S6, S11, S18, and S19 are also readily digested. As with the 50S r-proteins, limited proteolysis of $30 \mathrm{~S}$ r-proteins reports surface accessibility of protease sites more than their stage in the assembly process.

\section{Utility of the Present Method}

There are several advantages to using MALDI-MS as the detection step for limited proteolysis of ribosomes. Because molecular weight is an intrinsic property, a detection method that reports molecular weights can be used to directly identify those proteins resistant to proteolysis. In addition, when a protease of high specificity such as trypsin is used, the identification of proteolytic fragments is also possible, especially when the hydrolyzed peptide is from the $\mathrm{N}$ - or C-terminus of the protein. In that case, a simple comparison of measured molecular weight values to those predicted based 


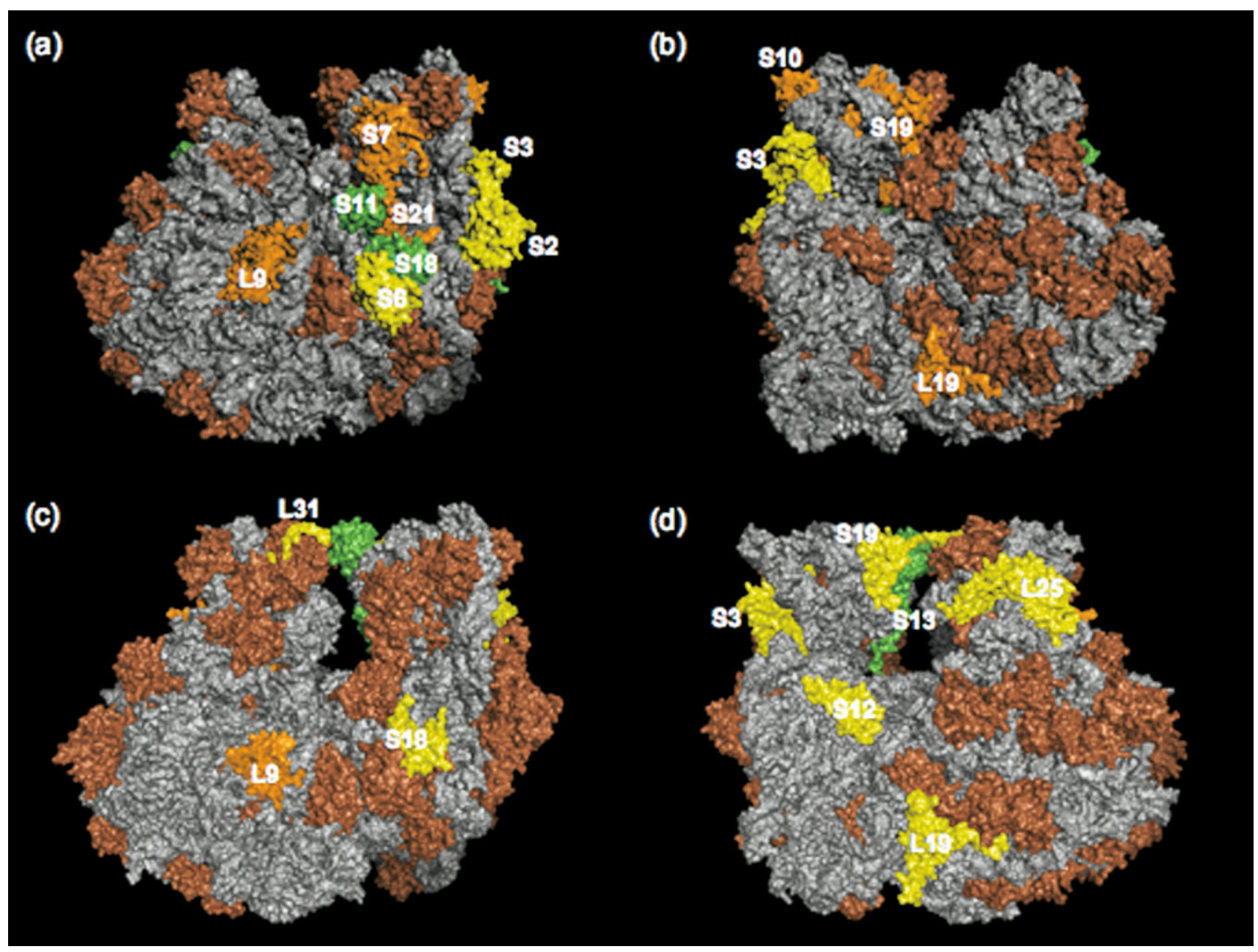

Figure 6. Surface presentation of the ribosomal proteins digested with both trypsin and Proteinase K. Color scheme: rRNA is represented in gray. Category one proteins (susceptible to digestion within $30 \mathrm{~min}$ ) are represented in yellow. Category two proteins (susceptible to digestion within $125 \mathrm{~min}$ ) are represented in green. Category three proteins (stable to digestion up to $1000 \mathrm{~min}$ ) are represented in orange (see text). Proteins that were still detected intact even after $1500 \mathrm{~min}$ of incubation are represented in brown. (a) and (b) Views of the surfaces of the E. coli $70 \mathrm{~S}$ ribosome with protease susceptible proteins identified. (a) to (b) are $180^{\circ}$ rotations about the vertical axis. (a) View from the left-hand side with the $30 \mathrm{~S}$ subunit on the right and the $50 \mathrm{~S}$ subunit on the left. (b) View from the right-hand side with the $30 \mathrm{~S}$ subunit on the left and the 50S subunit on the right. (c) and (d) Views of the surfaces of the T. thermophilus $70 \mathrm{~S}$ ribosome with protease susceptible proteins identified. (c) to (d) are $180^{\circ}$ rotations about the vertical axis with similar perspectives as for E. coli. Images of the $30 \mathrm{~S}$ and

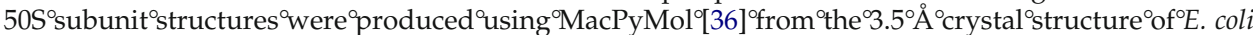
(accession $2 \mathrm{AVY}^{\circ}$ and $\left.2 \mathrm{AW} 4\right)^{\circ}[17]^{\circ}$ and ${ }^{\circ}$ the $2.8^{\circ} \mathrm{A}^{\circ} \mathrm{crystal}^{\circ}$ structure ${ }^{\circ}{ }^{\circ} \mathrm{T}$. thermophilus (accession $2 \mathrm{~J}^{\circ} 00^{\circ}$ and $2 \mathrm{~J} 01)^{\circ}[18]$.

upon loss of an $\mathrm{N}$ - or C-terminus tryptic peptide is all that is needed to assign the identity of the proteolytic fragment and site of proteolysis (Figures S5 and S6). When internal peptide domains are cleaved, data analysis and interpretation become more difficult primarily due to the greater number of theoretical cleavage masses that must be calculated. One limitation of the approach described here is that some r-proteins, L4, L5, S1, and S2 (T. thermophilus only) are not detected in the control experiments, although S1 is easily lost during most ribosome preparations. Furthermore, some proteins may be difficult to detect when all r-proteins are analyzed due to MALDI suppression effects as noted previously ${ }^{\circ}[48]^{\circ} .^{\circ}$ There $^{\circ}$ are $^{\circ}$ additional ${ }^{\circ}$ limitations ${ }^{\circ}$ of $^{\circ}$ this approach given the time resolution available to study ribosome conformations. For example, tracking conformational rearrangements during translation via the specific experimental procedure presented in this work would not provide sufficient time resolution to reveal any meaningful information on that process. However, this approach should be applicable to studies that investigate binding/release of external ribosome factors, providing such interactions are sufficiently longlived.

With the advent of high-resolution crystal structures $\left[17,{ }^{\circ} 18\right],{ }^{\circ} a^{\circ}$ significant $^{\circ}$ advancement ${ }^{\circ}$ in $^{\circ}$ our ${ }^{\circ}$ understand- 
ing of ribosome structure and function has resulted. However, ${ }^{\circ}$ as $^{\circ}$ has $^{\circ}$ been $^{\circ}$ noted $^{\circ}\left[49,{ }^{\circ} 50\right],{ }^{\circ}$ high-resolution crystal structures are limited to a very small number of organisms and information from one organism can inform but not directly replace information from another organism. Thus, methods such as that developed here, which reveal low-resolution information regarding ribosome organization are still necessary, and can be especially useful for organisms for which no highresolution crystal structures are yet available. As noted in this work, information obtained by MALDI-MS can provide specific identification of r-proteins relatively resistant to proteolytic digestion, can denote r-proteins readily digested, and can identify stable r-protein proteolytic fragments. The approach presented does not destroy the overall structure of ribosomal subunits, thus the MALDI data must be reporting on surface accessible r-proteins. One of the drawbacks of the direct MALDI-MS readout of ribosomal proteins and proteolytic fragments is that, in the absence of any detected proteolytic fragment, one cannot determine whether a particular r-protein is being digested by the protease. Although this drawback is not inherent to MALDI-MS, it does preclude obtaining quantitative data on protein stability in the absence of isotopic labeling or internal standards.

\section{Conclusions}

The use of MALDI-MS for the direct determination of r-proteins resistant to limited proteolysis has been demonstrated. This approach can be used at the level of intact ribosomes and can provide information on sites of proteolysis when proteases of high specificity are used. The approach yielded information of ribosome topology that is comparable to that previously obtained by other approaches. The speed and sensitivity of MALDI-MS, combined with the measurement of molecular mass, an intrinsic property of proteins, will allow this approach to be extended to ribosomes from additional organisms. Moreover, this approach provides a general route to obtaining information on the topology, organization, and conformational changes associated with RNP complexes.

The data obtained using E. coli and T. thermophilus ribosomes agrees well with existing crystal structures, suggesting that this method is applicable to additional organisms, including eukaryotic systems that are significantly larger and more complex. In addition to providing information on intact ribosomes, this approach should be applicable to examining ribosome dissociation processes, subunit associations, and conformational changes associated with the binding of external ribosomal factors. Another particularly useful extension of this method would be the investigation of other RNP complexes for which little high-resolution structural data exist, such as the ribosomal subunit assembly intermediates $945,96,51]$. Thus, ${ }^{\circ}$ while this 9 present ${ }^{\circ}$ study does not advance directly our understanding of the
E. coli or T. thermophilus ribosomes, it does demonstrate the feasibility of a relatively straight-forward and rapid mass spectrometric approach for limited proteolysis of large RNP complexes.

\section{Acknowledgments}

The authors thank Dr. Steven T. Gregory and Dr. Albert E. Dahlberg (Brown University) for the gift of T. thermophilus and Dr. S. Gregory and Dr. Yolanda Sanchez for helpful discussions. Financial support of this work was provided by the National Institutes of Health (GM 58843) and the University of Cincinnati.

\section{References}

1. Urlaub, H.; Kruft, V.; Bischof, O.; Muller, E.; Wittmann-Liebold, B. Protein-rRNA Binding Features and Their Structural and Functional Implications in Ribosomes as Determined by Cross-Linking Studies. EMBO J. 1995, 14, 4578-4588.

2. Thiede, B.; Urlaub, H.; Neubauer, H.; Grelle, G.; Wittmann-Liebold, B. Precise Determination of RNA-Protein Contact Sites in the 50S Ribosomal Subunit of Escherichia coli. Biochem. J. 1998, 334, 39-42.

3. Lambert, J. M.; Boileau, G.; Cover, J. A.; Traut, R. R. Cross-Links Between Ribosomal Proteins of 30S Subunits in 70S Tight-Couples and in 30 S Subunits. Biochemistry 1983, 22, 3913-3920.

4. Pohl, T.; Wittmann-Liebold, B. Identification of a Cross-Link in the Escherichia coli Ribosomal Protein Pair S13-S19 at the Amino Acid Level. J. Biol. Chem. 1988, 263, 4293-4301.

5. Spahn, C. M. T.; Beckmann, R.; Eswar, N.; Penczek, P. A.; Sali, A. Blobel, G.; Frank, J. Structure of the 80 S Ribosome from Saccharomyces cerevisiae - tRNA-Ribosome and Subunit-Subunit Interactions. Cell 2001, $107,373-386$.

6. Gao, H.; Sengupta, J.; Valle, M.; Korostelev, A.; Eswar, N.; Stagg, S. M.; Van Roey, P.; Agrawal, R. K.; Harvey, S. C.; Sali, A.; Chapman, M. S.; Frank, J. Study of the Structural Dynamics of the E. coli $70 S$ Ribosome Using Real-Space Refinement. Cell 2003, 113, 789-801.

7. Walleczek, J.; Schuler, D.; Stoffler-Meilicke, M.; Brimacombe, R.; Stoffler, G. A Model for the Spatial Arrangement of the Proteins in the Large Subunit of the Escherichia coli ribosome. EMBO J. 1988, 7, 3571-3576.

8. Agafonov, D. E.; Kolb, V. A.; Spirin, A. S. Proteins on Ribosome Surface: Measurements of protein exposure by hot tritium bombardment technique. Proc. Natl. Acad. Sci. U.S.A. 1997, 94, 12892-12897.

9. Christodoulou, J.; Larsson, G.; Fucini, P.; Connell, S. R.; Pertinhez, T. A.; Hanson, C. L.; Redfield, C.; Nierhaus, K. H.; Robinson, C. V Schleucher, J.; Dobson, C. M. Heteronuclear NMR Investigations of Dynamic Regions of intact Escherichia coli Ribosomes. Proc. Natl. Acad. Sci. U.S.A. 2004, 101, 10949-10954.

10. Yamamoto, T.; Izumi, S.; Gekko, K. Mass Spectrometry of Hydrogen/ Deuterium Exchange in 70S Ribosomal Proteins from E. coli. FEBS Lett. 2006, 580, 3638-3642.

11. Ilag, L.; Videler, H.; McKay, A.; Sobott, F.; Fucini, P.; Nierhaus, K.; Robinson, C. Heptameric (L12)6/L10 Rather Than Canonical Pentameric Complexes are Found by Tandem MS of Intact Ribosomes from Thermophilic Bacteria. Proc. Natl. Acad. Sci. U.S.A. 2005, 102, 8192-8197.

12. Rostom, A.; Fucini, P.; Benjamin, D.; Juenemann, R.; Nierhaus, K.; Hartl, F.; Dobson, C.; Robinson, C. Detection and Selective Dissociation of Intact Ribosomes in a Mass Spectrometer. Proc. Natl. Acad. Sci. U.S.A. 2000, 97, 5185-5190.

13. Benjamin, D.; Robinson, C.; Hendrick, J.; Hartl, F.; Dobson, C. Mass Spectrometry of Ribosomes and Ribosomal Subunits. Proc. Natl. Acad. Sci. USA 1998, 95, 7391-7395.

14. Ban, N.; Nissen, P.; Hansen, J.; Moore, P. B.; Steitz, T. A. The Complete Atomic Structure of the Large Ribosomal Subunit at 2.4 A Resolution. Science 2000, 289, 904-920.

15. Wimberly, B. T.; Broderson, D. E.; Clemons, W. M.; Morgan-Warrent, R. J.; Carter, A. P.; Vonrhein, C.; Hartsch, T.; Ramakrishnan, V. Structure of the 30S Ribosomal Subunit. Nature 2000, 407, 327-339.

16. Yusupov, M. M.; Yusupova, G. Z.; Baucom, A.; Lieberman, K.; Earnest, T. N.; Cate, J. H. D.; Noller, H. F. Crystal Structure of the Rribosome at $5.5 \AA$ A Resolution. Science 2001, 292, 883-896.

17. Schuwirth, B. S.; Borovinskaya, M. A.; Hau, C. W.; Zhang, W.; VilaSanjurjo, A.; Holton, J. M.; Cate, J. H. D. Structures of the Bacterial Ribosome at $3.5 \AA$ Resolution. Science 2005, 310, 827-834.

18. Selmer, M.; Dunham, C. M.; Murphy, I. V., F. V.; Weixlbaumer, A. Petry, S.; Kelley, A. C.; Weir, J. R.; Ramakrishnan, V. Structure of the 70S Ribosome Complexed with mRNA and tRNA. Science 2006, 313, 19351942.

19. Peng, B.-H.; Lee, J. C.; Campbell, G. A. In Vitro Protein Complex Formation with Cytoskeleton-anchoring Domain of Occludin Identified by Limited Proteolysis. J. Biol. Chem. 2003, 278, 49644-49651.

20. Meyer, E. L.; Strutz, N.; Gahring, L. C.; Rogers, S. W.; Glutamate Receptor. Subunit 3 Is Modified by Site-Specific Limited Proteolysis Including Cleavage by g-Secretase. J. Biol. Chem. 2003, 278, 23786-23796. 
21. Hijarrubia, M. J.; Aparicio, J. F.; Martin, J. F. Domain Structure Characterization of the Multifunctional $\alpha$-Aminoadipate Reductase from Penicillium chrysogenum by Limited Proteolysis. Activation of $\alpha$ Aminoadipate Does Not Require the Peptidyl Carrier Protein or the Reduction Domain. J. Biol. Chem. 2003, 278, 8250-8256.

22. Gudkov, A. T.; Gongadze, G. M. The L7/L12 Proteins Change Their Conformation Upon Interaction of EF-G with Ribosomes. FEBS Lett. 1984, 176, 32-36.

23. Kruft, V.; Wittmann-Liebold, B. Determination of Peptide Regions on the Surface of the Eubacterial and Archaebacterial Ribosome by Limit Proteolytic Digestion. Biochemistry 1991, 30, 11781-11787.

24. Cohen, S. L.; Ferre-D'amare, A. R.; Burley, S. K.; Chait, B. T. Probing the Solution Structure of the DNA-Binding Protein Max by a Combination of Proteolysis and Mass Spectrometry. Protein Sci. 1995, 4, 1088-1099.

25. Fontana, A.; Zambonin, M.; de Laureto, P. P.; Filippis, V. D.; Clementi, A.; Scaramella, E. Probing the Conformational State of Apomyoglobin by Limited Proteolysis. J. Mol. Biol. 1997, 266, 223-230.

26. Yang, F.; Cheng, Y.; Peng, J.; Zhou, J.; Jing, G. Probing the Conformational State of a Truncated Staphylococcal Nuclease R Using Time of Flight Mass Spectrometry with Limited Proteolysis. Eur. J. Biochem. 2001, 268, 4227-4232.

27. Leite, J. F.; Amoscato, A. A.; Cascio, M. Coupled Proteolytic and Mass Spectrometry Studies Indicate a Novel Topology for the Glycine Receptor. J. Biol. Chem. 2000, 275, 13683-13689.

28. Bothner, B.; Dong, X. F.; Bibbs, L.; Johnson, J. E.; Siuzdak, G. Evidence of Viral Capsid Dynamics Using Limited Proteolysis and Mass Spectrometry. J. Biol. Chem. 1998, 273, 673-676.

29. Gervasoni, P.; Staudenmann, W.; James, P.; Plueckthun, A. Identification of the Binding Surface on b-Lactamase for GroEL by Limited Proteolysis and MALDI-Mass Spectrometry. Biochemistry 1998, 37, 11660-11669.

30. Cameron, D. M.; Gregory, S. T.; Thompson, J.; Suh, M.-J.; Limbach, P. A.; Dahlberg, A. E. Thermus thermophilus L11 Methyltransferase, PrmA, Is Dispensable for Growth and Preferentially Modifies Free Ribosomal Protein L11 Prior to Ribosome Assembly. J. Bacteriol. 2004, $186,5819-5825$.

31. Spedding, G. In Ribosomes and Protein Synthesis: A Practical Approach; Oxford University Press: Oxford, 1990; pp 1-27.

32. Stanley, W. M., Jr.; Bock, R. M. Isolation and Physical Properties of the Ribosomal Ribonucleic Acid of Escherichia coli. Biochemistry 1965, 4, 1302-1311.

33. Rowley, A.; Choudhary, J. S.; Marzioch, M.; Ward, M. A.; Weir, M.; Solari, R. C. E.; Black, W. P. Application of Protein Mass Spectrometry in Cell Biology. Methods 2000, 20, 383-397.

34. Suh, M.-J.; Limbach, P. A. Investigation of Protein Isolation Methods Suitable for the Matrix-Assisted Laser Desorption/Ionization Mass Spectrometric Analysis of Ribonucleoprotein Complexes. Eur. J. Mass Spectrom. 2004, 10, 89-99.

35. Clauser, K. R.; Baker, P.; Burlingame, A. L. Role of Accurate Mass Measurement ( \pm 10 ppm) in Protein Identification Strategies Employing MS or MS/MS and Database Searching. Anal. Chem. 1999, 71, 2871-2882.
36. DeLano,, W. L. The PyMol Molecular Graphics System http://www. pymol.org. 2002. DeLano Scientific, Palo Alta, CA.

37. Brodersen, D. E.; Clemons, W. M.; Carter, A. P.; Wimberly, B. T.; Ramakrishnan, V. Crystal Structure of the 30 S Ribosomal Subunit from Thermus thermophilus: Structure of the Proteins and Their Interactions with 16 S RNA. J. Mol. Biol. 2002, 316, 725-768.

38. Noller, H. F.; Hoffarth, V.; Zimniak, L. Unusual Resistance of Peptidyl Transferase to Protein Extraction Procedures. Science 1992, 256, $1416-$ 1419.

39. Khaitovich, P.; Mankin, A. S.; Green, R.; Lancaster, L.; Noller, H. F. Characterization of Functionally Active Subribosomal Particles from Thermus aquaticus. Proc. Natl. Acad. Sci. U.S.A. 1999, 96, 85-90.

40. Littlechild, J.; Malcolm, A.; Paterakis, K.; Ackermann, I.; Dijk, J. The Tertiary Structure of Salt-Extracted Ribosomal Proteins from Escherichia coli as Studied by Proton Magnetic Resonance Spectroscopy and Limited Proteolysis Experiments. Biochim. Biophys. Acta 9132451987255.

41. Allers, J.; Shamoo, Y. Structure-Based Analysis of Protein-RNA Interactions Using the Program ENTANGLE. J. Mol. Biol. 2001, 311, 75-86.

42. Suh, M.-J.; Hamburg, D.-M.; Gregory, S. T.; Dahlberg, A. E.; Limbach, P. A. Extending Ribosomal. Protein Identifications to Unsequenced Bacterial Strains Using Matrix-Assisted Laser Desorption/Ionization Mass Spectrometry. Proteomics 2005, 5, 4818-4831.

43. Wilson, D. N.; Nierhaus, K. H. Ribosomal Proteins in the Spotlight. Crit. Rev. Biochem. Mol. Biol. 2005, 40, 243-267.

44. Dohme, F.; Nierhaus, K. H. Total Reconstitution and Assembly of $50 \mathrm{~S}$ SSubunits from Escherichia coli Ribosomes in Vitro. J. Mol. Biol. 1976, 107, 585-599.

45. Herold, M.; Nierhaus, K. Incorporation of Six Additional Proteins to Complete the Assembly Map of the 50 S Subunit from Escherichia coli ribosomes. J. Biol. Chem. 1987, 262, 8826-8833.

46. Held, W. A.; Ballou, B.; Mizushima, S.; Nomura, M. Assembly Mapping of 30S Ribosomal Proteins from Escherichia coli. Further Studies. J. Biol. Chem. 1974, 249, 3103-3111.

47. Mizushima, S.; Nomura, M. Assembly Mapping of 305 Ribosomal Proteins from E. coli. Nature 1970, 226, 1214-1218.

48. Arnold, R. J.; Reilly, J. P. Observation of E. coli Ribosomal Proteins and Their Post-Translational Modification by Mass Spectrometry. Anal. Biochem. 1999, 269, 105-112.

49. Sergiev, P.; Leonov, A.; Dokudovskaya, S.; Shpanchenko, O.; Dontsova, O.; Bogdanov, A.; Rinke-Appel, J.; Mueller, F.; Osswald, M.; von Knoblauch, K.; Brimacombe, R. Correlating the X-ray Structures for Halo- and Thermophilic Ribosomal Subunits with Biochemical Data for the Escherichia coli ribosome. In: The Ribosome; Cold Spring Harbor Laboratory Press: Cold Spring Harbor, NY; 2001, pp. 87-100.

50. Sergiev, P. V.; Dontsova, O. A.; Bogdanov, A. A. Chemical Methods for the Structural Study of the Ribosome: Judgment day. Mol. Biol. 2001, 35, 472-496.

51. Holmes, K. L.; Culver, G. M. Mapping Structural Differences Bbetween 30S Ribosomal Subunit Assembly Intermediates. Nat. Struct. Biol. 2004 11, 179-186. 